\title{
Komparasi Agama Terkait Pembangunan Rumah Ibadah Antara Lebak dan Pandeglang
}

Firda Afifah Damayanti ${ }^{1}$

Ilmu pemerintahan FISIP UNTIRTA

firdady02@gmail.com

Jimas Maulana ${ }^{2}$

Ilmu pemerintahan FISIP UNTIRTA

maulana.jimas@gmail.com

Rasifa Apriliana ${ }^{3}$

Ilmu pemerintahan FISIP UNTIRTA

rasifaapriliana06@gmail.com

\section{Ridwanul Maknunah ${ }^{4}$}

Ilmu pemerintahan FISIP UNTIRTA

ridwanulmaknunah123@gmail.com

\section{Riza Aulia $\mathbf{S}^{5}$}

Ilmu pemerintahan Fisip Untirta

rizaulia99@gmail.com

\section{E-ISSN (2721-0642)}

Recieved:

January 262021

Revised:

March 182021

Accepted:

April 142021

Doi Number

https://doi.org/10.37950/ijd.v3i1.81

\section{Abstract}

This paper aims to dissect the concept of how to compare religions related to houses of worship between Lebak and Pandeglang. Today, social society has a lot of diversity, including ethnicity, language, race, and religion. With so many differences and social diversity, society tends to cause divisions in the community environment. The differences that are present in the community are fostered by a unity that respects one another. The study in this article describes the side of Indonesian pluralism, especially the social conditions of the religious community in Lebak Regency. The challenges that are present in forming unity and respecting differences in the concept of multicultural pluralism are not clashed with disagreements and respect for the differences that exist in each individual. Neither government regulations or policies, both central and regional, do not limit the space for minority communities. The concept that is present in the community will lead to love for unity and peace. Lebak is a district in Banten Province, which is tolerant of differences. In the condition of a society that respects each other and chats with tolerance, the culture of the community that is different from the individuals in the environment, is able to understand the character of every human being, so that hate speech about a group is almost non-existent. However, in contrast to neighboring districts, Pandeglang has become a district nicknamed the city of santri in Banten province, which is quite intolerant of nonMuslims. One of which is the community rejects the construction of non-Muslim places of 
Volume 3, Issue 1, April 2021

http://hk-publishing.id/ijd-demos

worship in Pandeglang district. Of course this shows a clear allusion that looks like distinguishing the right to religion and worship only in Islam.

Keywords: multiculturalism, pluralism, identity, comparison

\begin{abstract}
Abstrak
Tulisan ini bertujuan untuk membedah konsep bagaimana Komparasi Agama Terkait Rumah Ibadah Antara Lebak dan Pandeglang. Dewasa ini sosial masyarakat memiliki banyak keberagaman, baik suku, bahasa, ras, maupun agama. Dengan banyaknya perbedaan serta keberagaman sosial masyarakat cenderung menimbulkan perpecahan dalam lingkungan masyarakat tersebut. Perbedaan yang hadir ditengah masyarakat dipupuk dengan persatuan yang saling menghargai satu sama lain. Kajian dalam artikel ini mendeskripsikan sisi pluralism Indonesia terkhusus kondisi sosial umat beragama di Kabupaten Lebak. Tantangan yang hadir dalam membentuk persatuan dan saling menghargai perbedaan dalam konsep pluralism multikultularilsm tidak dibenturkan dengan perselisih paham dan menghargai perbedaan yang ada pada setiap individu. Baik aturan atau kebijakan pemerintah baik pusat ataupun daerah, tidak membatasi ruang terhadap masyarakat minoritas. Konsep yang hadir ditengah masyarakat tersebut akan menimbulkan cinta persatuan dan perdamaian. Lebak merupakan kabupaten yang berada di Provinsi Banten, menjdi salah-satu daerah yang toleran terhadap perbedaan. Dalam kondisi masyarakat yang saling menghargai dan bercengkrama dengan toleransi, budaya masyarakat yang berbeda dengan individu yang ada di lingkungan tersebut, mampu memahami karakter setiap insan, sehingga ujaran kebencian akan suatu kelompok hampir tidak ada kasus. Namun beda dengan Kabupaten tetangganya, Pandeglang malah menjadi sebuah kabupaten yamng di juluki kota santri di provinsi Banten cukup intoleran terhadap non-muslim. Yang salah satunya masyarakat menolak pembanguan rumah ibadah non-muslim di kabupaten pandeglang. Tentu hal ini menunjukan adanya singgungan jelas yang terlihat seperti membedakan hak beragama dan beribadah hanya ada pada agama islam.
\end{abstract}

Kata Kunci: multikulturalisme, pluralisme, identitas, komparasi

\title{
Pendahuluan
}

Indonesia merupakan suatu negara yang menjunjung tinggi nilai-ilai toleransi dalam berbangsa dan bernegara. Berbagai suku bangsa, budaya, agama, dan ras berada dalam satu kepulauan Indonesia. Di Indonesia sendiri memiliki 5 keyakinan agama yaitu agama Islam, Kristen, Katolik, Hindu, dan Buddha. Agama dijadikan manusia sebagai pedoman hidup lebih teratur, terkontrol, terarah dan terkelola dengan baik berdasarkan jalan kehidupan yang sesuai dengan intruksi tuhan melalui kegiatan ibadah. Adanya perbedaan-perbedaan dari setiap agama membuat masyarakat Indonesia untuk bersikap toleransi saling menghargai, saling menghormati, juga saling menyayangi antar sesama masyarakat Indonesia.

Indonesia memiliki banyak agama yang sering kali terjadi konflik sosial antar umat beragama. Konflik sosial yang terjadi di Indonesia, baik dalam ruang lingkup besar maupun kecil telah membawa perpecahan bagi kehidupan berbangsa dan 
bernegara. Bangsa Indonesia sangat berpegang teguh dan mengembangkan falsafah kehidupan dengan menjunjung tinggi peraturan sosial berdasarkan pancasila, UUD 1945, dan peraturan perundang-undangan lainnya. Hal ini merupakan sebagai kebebasan berbasis tanggung jawab sosial dari kebebasan yang kita kembangkan masyarakat Indonesia dapat dikatakan sebagai masyarakat yang multikultular, arti masyarakat multikultular itu sendiri yaitu merupakan masyarakat yang mempunyai kehidupan dengan banyaknya ke anekaragaman budaya maupun kultur.

Dalam penelitian kali Ini kami mengambil judul yaitu "perspektif sosial terhadap toleransi umat beragama di kabupaten Lebak". Dengan studi kasus toleransi umat beragama Islam, Hindu dan Budha. Dimana kita ketahui bahwa di kabupaten Lebak terdapat berbagai agama yang diyakini dan berkembang di masyarakat. Banyaknya perbedaan serta keberagaman sosial masyarakat cenderung menimbulkan perpecahan dalam lingkungan masyarakat tersebut. Perbedaan yang hadir ditengah masyarakat dipupuk dengan persatuan yang saling menghargai satu sama lain. Oleh karena itu toleransi dalam beragama sanagat penting dalam kehidupan beragama, karena bertoleransi sangat memberikan dan membangun kehidupan beragama agar kehidupan menjadi rukun, tentram, sejahtra dan menjauhi adanya konflik beragama yang dapat memecah belah bangsa dan Negara.

\section{Kerangka Teori \\ Teori Identitas}

Definisi dari identitas dapat merujuk kepada asal katanya yaitu identity, yang merupakan keadaan seseorang yang mempuyai kemiripan dengan yang lain (Riswanda et al., 2020), kondisi yang menjelaskan kesamaan atas suatu benda ataupun seseorang, fakta yang menjelaskan kesamaan atas dua kelompok yang berbeda, ataupun hanya menyatakan kemiripan satu sama lain (Liliweri, 2007: 69).

Untuk mengenal masyarakat, diperlukan pemahaman mengenai identitas dari masyaakat itu sendiri, yang disebut dengan identitas sosial. Menurut (Jenkins, 2008:15), identitas sosial adalah ciri khas dari kelompok masyarakat yang menggambarkan kolektivitas kelompok tersebut yang berbeda dengan kolektivitas kelompok lain (Kymlicka, 2011).

Identitas adalah kenyataan yang ada dalam kehidupan masyarakat, identitas masyarkat terbentuk melalui proses sosial, dimana setiap orang akan memahami dirinya sendiri yang tergabung dalam sejarah masyarakat untuk mengenal kesamaannya dengan orang lain (Berger dan Lukman, 1990: 235). Menurut (Liliwer, 2007:95), identitas dikelompokan menjadi tiga bentuk, yaitu sebagai berikut:

\section{Identitas Budaya}

Identitas budaya merupakan ciri khas yang melekat pada seseorang yang merupakan bagian dari suatu kelompok tertentu, dimana terdapat pembelajaran yang terinternalisasi dalam diri seseorang mengenai tradisi, sifat yang mandarah daging, Bahasa, sikap, adat istiadat, agama, ataupun kepercayaan dari kelompok yang bersangkutan.

\section{Identitas Sosial}

Identitas sosial diartikan dengan melihat pemahaman seseorang terhadap sikap yang menyangkut pada keadaan sosial. Dimana, identitas sosial hadir untuk melihat adanya persamaan ataupun perbedaan yang dimiliki dengan orang lain. Berbicara mengenai 
identitas sosial pun juga melekat pada bagaimana suatu kelompok berinteraksi satu sama lain dan memperlihatkan ciri khasnya baik dari segi budaya, adat, ataupun sikap yang dapat membedakannya dengan kelompok lain.

\section{Identitas Diri}

Identitas diri diartikan sebagai kesadaran seseorang terhadap gambaran atas dirinya sendiri. Dimana, seseorang akan menilai ciri khas atau permasaan dan perbedaan ia dengan seseorang atau sekelompok orang dalam masyarakat. Identitas diri juga membahas mengenai ciri fisik ataupun keyakinan-keyakinanya atas suatu persoalan. Hal tersebut lah yang membuat seseorang mengenai siapa dirinya dan bagaimana ia harus bersikap di dalam masyarakat.

\section{Teori Pluralisme dan Multikultural}

Pluralisme agama atau pluralitas agama atau kebhinekaan agama merupakan kenyataan aksiomatis (tidak bisa dibantah), dan merupakan keniscayaan sejarah (historical necessary) yang bersifat universal. Pluralitas agama harus dipandang sebagai bagian dari kehidupan manusia, yang tidak dapat dilenyapkan, tetapi harus disikapi. Pluralisme agama berpotensi melahirkan benturan, konflik, kekerasan, dan sikap anarkis terhadap penganut agama lain (Hikmawan, 2017).

5 Potensi ini disebabkan karena setiap ajaran agama memiliki aspek ekslusif berupa truth claim, yaitu pengakuan bahwa agamanya yang paling benar. Tuhan yang disembah, Nabi yang membawa wahyu, syariat atau ajaran agama yang dimiliki dan diyakini sebagai yang paling benar. Konsekuensinya adalah agama lain dianggap tidak benar dan sesat. Agama yang benar harus meluruskan dan mengembalikan manusia ke jalan yang benar, masuk dalam agama mereka. Tidak mengherankan jika seluruh agama berlomba-lomba melakukan dakwah untuk mendapatkan pengikut sebanyakbanyaknya

Secara harafiah, multikultural berasal dari dua kata yaitu "multi" yang berarti banyak dan "kultural" yang berarti budaya. Sehingga, dapat dipahami bahwa multikultural merupakan keberagaman budaya yang ada dalam masyarakat (Banting \& Kymlicka, 2013; Kymlicka, 1995) Apabila dilihat dari perjalanna sejarah dan geografis, Indonesia kedatangan berbagai macam suku dengan budaya yang berbeda. Selain itu, secara georafis Indonesia mempunyai wilayah yang luas sehingga sudah pasti mempunyai banyak budaya yang berbeda. Kemajemukan yang ada di Indonesia membuat Bahasa, budaya, agama, kepercayaan, suku, ras, ataupun adat istiadat di Indonesia sangat beragam.

Menurut (Wadatul, 2016), setiap orang pada dasarnya pasti mempunyai perbedaan satu sama lain, tidak terdapat kesamaan anatara satu sama lain secara utuh. Dengan demikian, yang menjadi ciri khas setidaknya pada suatu kelompok masyarakat adalah budayanya (Hikmawan, 2014). Kebudayaan yang berbeda menjadi identitas dari suatu masyarakat sebagai pembeda dengan kelompok masyarakat lain. Perbedaan budaya ini biasanya tercermin dari kelompok masyarakat adat yang terpencar di Indonesia. Masyarakat adat di Indonesia hingga saat ini masih melestarikan budaya dan kepercayaan mereka dan diturunkan kepada penerusnya.

Konsep multikultural sudah melekat pada bangsa Indonesia sebagai suatu pencerminan yang menjelaskan keberagaman yang hidup di masyarakat. Menurut (Rivai, 2004:7), multikultural merupakan sikap, pandangan, ataupun gagasan yang terdapat pada suatu masyarakat yang beragam akan suku, ras, agama, kepercayaan, 
dan sebagainya, dengan semangat untuk mempertahankan keberagaman tersebut (Hikmawan, 2020).

Istilah dari budaya mencerminkan berbagai hal, sehingga membuat pengertian dan pemahamannya multitafsir, hal ini dikarenakan, pengertian budaya mempunyai cakupan yang luas yang juga berhubungan dengan kepercayaan politik serta ideologi dari seseorang atau sekelompok orang (Sulalah, 2012: 42). Pemah aman akan kemajemukan yang hidup diantara masyarakat dapat dilakukan dengan berbagai upaya untuk mencegah perpecahan karena perbedaan tersebut. Salah satu caranya adalah memperkuat edukasi masyarakat bahkan sejak dini mengenai siapa bangsa Indonesia itu. Masyarakat harus memahami bahwa kehidupan bermasyarakat di Indonesia tidak hanya condong pada satu budaya atau keyakinan saya, melainkan terdapat pula cara pandang dan cara hidup yang berbeda satu sama lain. Dengan adanya pemahaman bangsa Indonesia adalah beragam, maka diharapkan akan meningkatkan perasaan toleransi dan sikap yang saling berangkul satu sama lain.

\section{Teori Perbandingan}

Dalam kamus Bahasa Indonesia lengkap bahwa perbandingan berasal dari kata banding yang artinya "persamaan", lalu membandingkan mempunyai arti lain yang berperinsip pada dua hal yaitu untuk diketahui perbandinganya, dan perbandingan dapat di artikan sebagai salah satu selisih persamaan (Bambang Marhiyanto;57)

Menurut Sjachran Basah (1994:7), Adapun perbandingan menurut suatu metode pengkajian atau penelitian dengan mengadakan perbandingan diatara beberapa objek dengan objek lain untuk lebih mengetahui objek yang dikaji dan memperdalam suatu metedo penelitian yang sedang di kaji.

Dalam metode ilmu hukum, perbandingan memiliki objek yang berbeda-beda dengan ilmu-ilmu lainya, Menurut Surjati Hartono, (1991:26), Didalam perbandingan tidak ada yang mendefinisikan khusus baik dari segi undang-undang, dan litelatur ataupun pendapat para sarjana, adanya perbandingan hanya untuk menlingkup suatu metode sehingga dapat di pelajari dari ilmu sosial-sosial lainya.

Dalam Analisis perbandingan terbagi menjadi tiga tahap yaitu: tahap pertama merupakan kegiatan dikriptif yaitu untuk mencari berita atau wawancara, dan tahap kedua memilih hasil wawancara berdasarkan data tertentu yang kita dapat dan tahap terakhir menyimpulkan data yang didapat untuk di kaji disatukan dalam berbagai variable, dalam studi perbandingan kita bisa mengatahui tentang Lembaga-lembaga yang terbentuk. (Mochtar Mas'oed; 2008; 26-29).

\section{Metode Penelitian}

Metode penelitian adalah sebuah cara peneliti untuk mencari data informasi yang digunakan untuk memperkuat hasil observasi baik secara kualitatif ataupun kuantitatif. Data-informasi yang di dapat dilapangan menjadi sebuah hasil penelitian hingga akhirnya dapat dijadikan sebuah karya ilmiah. Objek dari penelitian ini yaitu Komparasi Agama Terkait Pembangunan Rumah Ibadah Antara Lebak Dan Pandeglang.

Metode penelitian yang digunakan yaitu menggunakan metode kualitatifdeskriptifnyang juga melakukan observasi kelapangan untuk melihat secara langsung kondisi sosial masyarakat. Metode yang menggunakan buku-buku, literature serta referensi perpustakaan ini menjadi metode utama dalam mencari informasi, 
dikarenakan mengingatkan histories yang melekat pada daerah atau kabupaten yang di observasi.

\section{Hasil dan Pembahasan}

Dalam bernegara dan berbangsa, hak rakyat sama dalam konsep Negara demokrasi. Dimana Indonesia membentuk sebuah tatanan kehidupoan bergenara dengan seadil-adilnya dan sebaik-baiknya. Sama dengan arti dari toleransi umat beragama. Dimana ada sebuah hak yang tidak bisa di renggut oleh siapapun. Hak-hak beribadah, bertuhan diatur dalam undang-undang 1945 dan dipertegas dalam poin satu pancasila. Oleh karena itu, setiap manusia berhak memeluk dan beribadah sesuai dengan kepercayaan dan keyakinannya masing-masing. Maka kita sebagai makhluk sosial perlu adanya sifat toleransi atau saling menghargai kepada setiap makhluk hidup satu sama lain, terutama menghargai dan menghormati antara sesama manusia yang beragama. Namun demikian belum semua manusia menerapkan konsep toleransi antar umat beragama, seperti salah satunya studi kasus Komparasi Agama Terkait Pembangunan Rumah Ibadah Antara Lebak Dan Pandeglang

\section{Toleransi Lebak}

Lebak merupakan sebuah kabupaten yang terletak di sebelah selatan provinsi Banten. Dimana lebak sendiri adalah daerah yang terkenal dengan kerifan local yang sampai saat ini masih dibudayakan bahkan bukan hanya tingkat nasional, tapi terdengar sampai kancah internasional, seperti adat baduy dan kesepuhan-kasepuhan desa adat.

Bukan hanya itu, lebak kecil kasus untuk persoalan konflik SARA. Dimana data mencapai $0,1 \%$ isu SARA antar golongan tidak terdeteksi. Sebuah daerah yang memiliki toleransi serta ramah terhadap pendatang, menjadikan daerah kabupaten lebak sebagai salah-satu tempat pariwisata yang banyak dikunjungi salahsatunya museum multatulli.

Toleransi umat beragama sudah cukup lama diterapak dikota angklung ini. Dimana semenjak raja tarumanegara masih dalam kerajaan pasundaan umat beragam sudah hadir yaitu hindu-budha-kristen. Dimana kasus ini menjadi sebuah permulaan masuknya islam dan diterima oleh kalangan masyarakat sipil dan bangsawan pasundaan.

Pembanguan rumah umat beragama sudah lama terlahir dan sangat sedikit kasus yang terjadfi isu SARA yang menyebabkan terjadinya bentrokan antar umat beragama. Masyarakat lebak sangat bertoleransi atau saling menghargai dan menghormati terhadap pembangunan rumah agama di lebak seperti dibuktikan pada daerah Rangkasbitung dimana disana terdapat sejumlah rumah ibadah seperti masjid, gereja, vihara dan lainnya. 


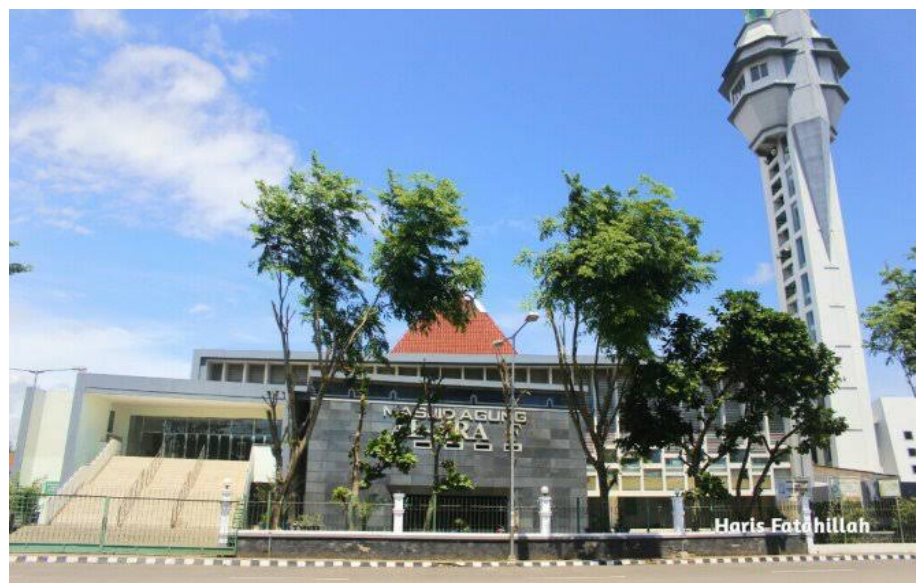

(Masjid Agung Al-A'Raaf Rangkasbitung-Lebak)

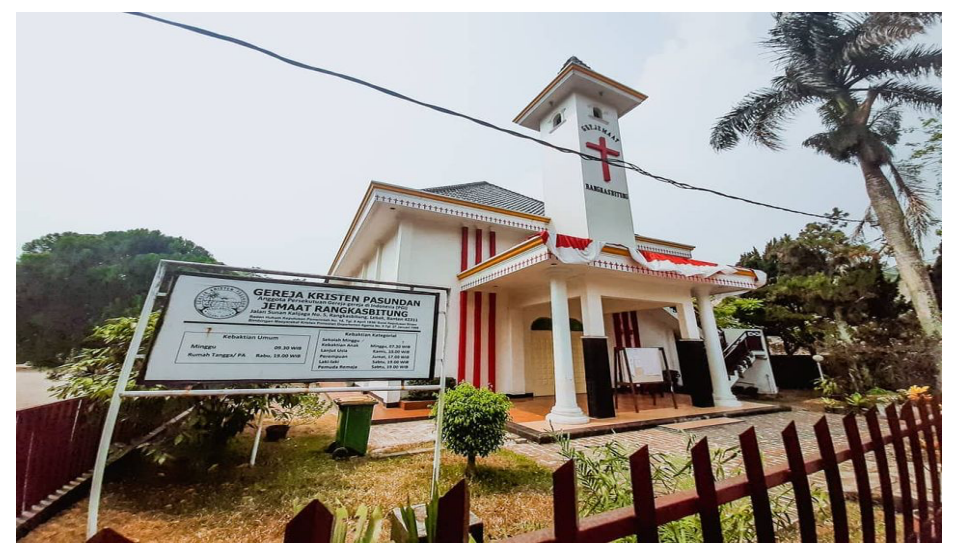

(Gereja Kristen Pasundan Rangkasbitung-Lebak)

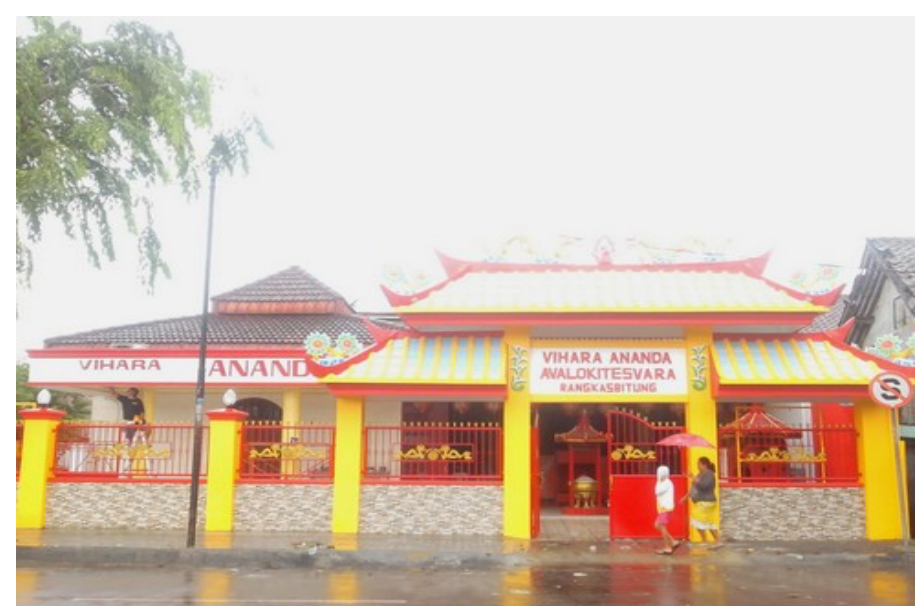

(Vihara Ananda Avalokitesvara Rangkasbitung-Lebak)

\section{Toleransi Pandeglang}

Pandeglang merupakan sebuah wilayah atrau kabupaten yang berada di provinsi banten. Dimana kabupaten opandeglang merupakan sebuah kota yang dijuluki sebagai kota santri. Dimana sangat banyaknya pondok pesantren dan para ulama atau tokoh islam hingga menuai sebuatan pandeglang sebagai kota santri. Slah satunya ulama besar pun lahir di kota pandegalang yang menjadi imam bagi sebagian besar umat bislam di Indonesia. 
Bagaiman dengan toleransi umat beragam di kabupaten pandeglang? Toleransi dipandeglang terhadap umat beragam cukup miris. Dimana ada banyak kasus di pandeglang salah satu penyebabnya adalah keyakinan yang berbeda. Bahkan dalam satu agama namun bernbeda tatacara beribadah menjadi sebuah cara untuk konflik baru.

Ditahun 2018 banyak penolakjan adanya pembvanguan gereja didaerah carita, ditahun 2012 adanya peretempuran atau knflik terhadap golongan ahmadiyah dan islam setempat, dan banyak kasus lainnya ya ng menjadikan pandeglang sangat kuat akan keislaman yang bersyariat. Walaupun saat ini sudah adanya rumah ibadah nonmuslim, namun kasus-kasus baru terhadap isu sara masih saja sangat kuat dan menjadikan perbandingan dengan kabupaten lebak.

Kabupaten lebak dan pandeglang memiliki ciri karakter yang sama, yaitu watak yang keras. Namun kulturalisasi di dua kabupaten ini cukup berbanding terbalik, dan humanity secara garis kebebasan dalam memeluk keyakinan serta hak-haknya sedikit terenggut dan bterganggu jika melihat kasus komperasi lebak dan pandeglang. Maka dapat dinyatakan bahwa di pandeglang terdapat adanya intoleransi terhadap agama non muslim apalagi terkait dalam pembangunan rumah ibadah di kabupaten pandeglang.

\section{Tentang penulis}

Firda Afifah Damayanti merupakan mahasiswa Ilmu Pemerintahan, Fakultas Ilmu Sosial dan Ilmu Politik Universitas Sultan Ageng Tirtayasa.

Jimas Maulana merupakan mahasiswa Ilmu Pemerintahan, Fakultas Ilmu Sosial dan Ilmu Politik Universitas Sultan Ageng Tirtayasa.

Rasifa Apriliana merupakan mahasiswa Ilmu Pemerintahan, Fakultas Ilmu Sosial dan Ilmu Politik Universitas Sultan Ageng Tirtayasa.

Ridwanul Maknunah merupakan mahasiswa Ilmu Pemerintahan, Fakultas Ilmu Sosial dan Ilmu Politik Universitas Sultan Ageng Tirtayasa.

Riza Aulia S merupakan mahasiswa Ilmu Pemerintahan, Fakultas Ilmu Sosial dan Ilmu Politik Universitas Sultan Ageng Tirtayasa.

\section{Ucapan Terimakasih}

Penulis mengucapkan terimakasih kepada M. Dian hikmawan, M.A selaku dosen pengampu mata kuliah Politik Identitas dan Multikulturalisme yang telah membimbing penulis hingga penelitian ini dapat terselesaikan. Terimakasih kepada Masyarakat Lebak dan Pandeglang yang telah koopratrif dalam memberikan informasi yang dibutuhkan dalam penelitian ini. Terimakasih kepada prodi ilmu pemerintahan dan semua pihak yang berperan dalam penelitian ini.

\section{Referensi}

Baldah, Wardatul, dkk. Pengaruh Penanaman Nilai-nilai Multikultural terhadap Pembentukan Sikap Pluralis Siswa di MTS N Ciwaringin Kab. Cirebon. Jurnal Edukos Volume V NO,1 Juni 2016.

Banting, K., \& Kymlicka, W. (2013). Multiculturalism and the Welfare State Recognition and Redistribution in Contemporary Democracies Publication. Etica e Politica, 15(1), 
Volume 3, Issue 1, April 2021

http://hk-publishing.id/ijd-demos

583-605. https:/ / doi.org/10.1093/acprof

Berger, Peter L. dan Thomas Lukman. Tafsir Sosial atas Kenyataan, Risalah Tentang Sosiologi Pengetahuan. Jakarta: LP3ES, 1990.

Harahap, Ahmad Rivai. Multikulturalisme dan Penerapannya dalam Pemeliharaan Kerukunan Umat Beragama. 2004.

Hikmawan, M. D. (2014). Politik Perbedaan : Demokrasi dalam Paradoks. Universitas Gdjah Mada.

Hikmawan, M. D. (2017). Pluralisme Demokrasi Politik di Indonesia. Journal of Governance, 2(2), 223-247. https://doi.org/http://dx.doi.org/10.31506/jog.v2i2.2678

Hikmawan, M. D. (2020). Consensual Democracy: A Challenge for Differentiated Citizenship. In International Journal of Innovation, Creativity and Change. www.ijicc.net (Vol. 11, Issue 2). www.ijicc.net

Jenkins, Richard. Social Identity. Third Edition. United Kingdom: Routledge, 2008.

Kymlicka, W. (1995). Multicultural Citizenship A Liberal Theory of Minority Rights. Oxford University Press.

Kymlicka, W. (2011). Multicultural Odysseys: Navigating the New International Politics of Diversity. In Oxford University Press. https:/ / doi.org/10.1163/174552411x549327

Liliweri, Alo Makna Budaya Dalam Komunikasi Antar Budaya. Yogyakarta: PT LkiS Pelangi Angkasa, 2007.

Riswanda, M., Hikmawan, D., Ramadhan, G., \& Nurrohman, B. (2020). Making sense of the politics of recognition: Indicators of religious tolerance in Banten, Indonesia. International Journal of Engineering Research and Technology, 13(11).

Sulalah. Pendidikan Multikultural Didaktika Nilai-nilai Universal Kebangsaan. Malang: UIN Maliki Press, 2012. 